\title{
The Nature of Life
}

\section{Sujith Kumar Mullapally ${ }^{1, \odot}$ \\ ${ }^{1}$ Department of Medical Oncology, Apollo Proton Cancer Centre, Chennai, India}

Ind J Med Paediatr Oncol 2021;42:177.
Address for correspondence Dr Sujith Kumar Mullapally MD, DNB, DM, (Medical Oncology), Apollo Proton Cancer Centre, 4/661, Dr Vikram Sarabai Instronic Estate 7th St, Dr. Vasi Estate, Phase II, Tharamani, Chennai, Tamil Nadu, 600096, India (e-mail: drsujithm@gmail.com).

More unknown in this world than truly known,

More unseen in world than your own little town,

Take time out from this clinical rush and life's race,

Mountains are ever calling to give you solace.

As you watch life blooming in the valley spread far,

A speck of dust in universe is all that we are;

The color of our life, the shades of vast experience,

So trivial stands in front of her beauty, magnificence,

Much more to learn from Nature than from books.

When we look further into depth, frozen by her looks,

In the solitude on the heights as I stood, fully awake,

Got numb in admiration of her serenity, majestic make.

I self-realize living life to the fullest is the only worthy goal,

No time to quarrel, complain, or be with heart small.

I feel refreshed, charged up enough to excel in care,

Treat and guide cancer patients out of their despair,

Steady and calm becomes my mind, ego got drown,

Oh Mother Nature, to you, I humbly bow down!!

DOI https://doi.org/

$10.1055 / s-0041-1733828$

ISSN 0971-5851
(C) 2021. Indian Society of Medical and Paediatric Oncology.

This is an open access article published by Thieme under the terms of the Creative Commons Attribution-NonDerivative-NonCommercial-License, permitting copying and reproduction so long as the original work is given appropriate credit. Contents may not be used for commercial purposes, or adapted, remixed, transformed or built upon. (https://creativecommons.org/licenses/by-nc-nd/4.0/).

Thieme Medical and Scientific Publishers Private Ltd. A-12, Second

Floor, Sector -2, NOIDA -201301, India 